\title{
ANALISIS KESALAHAN BERBAHASA INDONESIA DI BIDANG WACANA DALAM IKLAN PRODUK - PRODUK INDONESIA
}

\author{
Dicky Restu Tomo ${ }^{1}$, Dewi Azizah Damaryanti ${ }^{2}$, Oktavia Dhiya Rofifah ${ }^{3}$, M. Wian Arifana ${ }^{4}$
}

\author{
${ }^{1}$ Program Studi Pendidikan Bahasa dan Sastra Indonesia Universitas Ahmad Dahlan, \\ dickyrestut@gmail.com \\ ${ }^{2}$ Program Studi Pendidikan Bahasa dan Sastra Indonesia Universitas Ahmad Dahlan, \\ dezahdamaryanti@gmail.com \\ ${ }^{3}$ Program Studi Pendidikan Bahasa dan Sastra Indonesia Universitas Ahmad Dahlan, \\ oktaviadhiyarofifah@gmail.com \\ ${ }^{4}$ Program Studi Pendidikan Bahasa dan Sastra Indonesia Universitas Ahmad Dahlan \\ $\underline{\text { m1700003140@webmail.uad.ac.id }}$
}

\begin{abstract}
The purpose of this study is to describe the mistakes of Indonesian language in the field of discourse on the advertising of products in Indonesia. The ads analyzed are food ads, drinks, beauty soaps, and others. This research uses descriptive method through two stages namely the stage of data collection and data analysis. The chosen research subject is advertising Indonesian products using written language. While the object is the analysis of errors in the Indonesian language in the field of discourse. The results obtained from this study were found 1 data referencing error usage, 2 data recovery use errors (substitution), 1 data ineffectiveness discourse because there is no impregnation, 1 data conjunction error, 1 data incoherent discourse, 2 error data that deviate from Indonesian language rules, and 2 data on force / ambiguity.
\end{abstract}

Keywords: Language error, discourse, advertising.

\begin{abstract}
ABSTRAK
Tujuan penelitian ini ialah untuk mendeskripsikan kesalahan berbahasa Indonesia di bidang wacana pada iklan produk - produk di Indonesia. Iklan yang dianalisis adalah iklan makanan, muinuman, sabun kecantikan, dan lain-lain. Penelitian ini menggunakan metode deskriptif yang melalui dua tahap yaitu tahap pengumpulan data dan analisis data. Subjek penelitian yang dipilih yaitu iklan produk-produk Indonesia yang mengguanakan bahasa tulis. Sedangkan objeknya yaitu analisis kesalahan berbahasa Indonesia di bidang wacana. Hasil yang diperoleh dari penelitian ini adalah ditemukan sebanyak 1 data kesalahan penggunaan pengacuan, 2 data kesalahan penggunaan penyulihan (substitution), 1 data ketidakefektifan wacana karena tidak ada pelesapan, 1 data kesalahan konjungsi, 1 data wacana tidak koherens, 2 data kesalahan yang menyimpang dari kaidah Bahasa Indonesia, dan 2 data ketaksaan/ambiguitas.
\end{abstract}

Kata kunci : Kesalahan berbahasa, wacana, iklan.

How to Cite: Restu Tomo, D., Azizah Damaryanti, D., Dhiya Rofifah, O., \& Wian Arifana , M. (2020). ANALISIS KESALAHAN BERBAHASA INDONESIA DI BIDANG WACANA DALAM IKLAN PRODUK - PRODUK INDONESIA. Bahtera Indonesia; Jurnal Penelitian Bahasa Dan Sastra Indonesia , 5(2), 192-203. https://doi.org/10.31943/bi.v5i2.82 
DOI: https://doi.org/10.31943/bi.v5i2.82

\section{PENDAHULUAN}

Bahasa merupakan sebuah alat yang memudahakan manusia sebagai mahluk social untuk berkomunikasi, bahasa berarti sistem yang mempunyai lambang bunyi yang arbitrer, yang digunakan oleh semua orang / anggota kemasyarakatan untuk saling bekerjasama, berinteraksi, dan saling mengidentifikasi diri dalam bentuk percakapan yg baik, tingkah laku yang baik, dan sopan santun yang baik juga ( Alwi, 2002: 88 ). Bahasa dibedakan menjadi dua yaitu bahasa tulis dan lisan, kaitanya dengan kegiatan memasarkan produk-produk dalam bentuk bahasa tulis (teks) yaitu iklan.

Penguasaan berbahasa yang dapat menarik minat pembeli serta dapat bersaing dengan produk pesaing menjadi elemen yang sangat penting dalam iklan. Pada sebuah iklan adanya bahasa tulis berupa (teks) singkat untuk mendeskripsikan produk sekaligus mempromosikannya kepada masyarakat merupakan bagian dari iklan penawaran. Walaupun singkat, bahasa tulis (teks) yang terdapat dalam iklan produk-produk Indonesia tidak terlepas dari aspek wacana.

Wacana merupakan satuan bahasa terlengkap dan tertinggi atau terbesar atas kalimat atau klausa dengan koherensi dan kohesi tertinggi yang berkesinambungan yang mempunyai awal dan ahir nyata disampaikan lisan atau tertulis (Tarigan 1987 :27 ). Dalam hal ini masih terdapat adanya kesalahan wacana pada teks iklan. Hal itulah yang menjadi fokus utama pembahasan dalam artikel jurnal ini, yakni memaparkan hasil analisis kesalahan wacana pada teks iklan produk-produk Indonesia.

Kohesi dalam wacana diartikan sebagai kepaduan bentuk yang secara struktural membentuk ikatan sintaktikal. Kalimat-kalimat yang kohesif ditandai oleh adanya piranti kohesi. Halliday dan Hassan (1976:21) membagi peranti kohesi wacana ke dalam dua kelompok: kohesi gramatikal dan kohesi leksikal. Yang termasuk kohesi gramatikal adalah referensi (GR), substitusi (GS), elipsis (GE), dan konjungsi (GK), sedangkan yang termasuk kohesi leksikal adalah repetisi (LR), sinonimi (LS), antonimi (LA), hiponimi (LH), dan kolokasi (LK). Kesembilan macam peranti kohesi akan dipaparkan secara singkat yaitu Referensi (penunjukan) diartikan sebagai suatu bentuk yang merujuk ke bentuk lainnya (Oktavianus, 2006:54). Referensi berkaitan dengan penggunaan kata atau kelompok kata untuk menunjuk kata atau 
kelompok kata atau satuan gramatikal lainnya (Ramlan, 1993:12). Referensi dibagi menjadi dua bagian: endofora dan eksofora. Apabila unsur yang diacu berada dalam teks, hubungan referensinya disebut endofora. Sebaliknya, apabila unsur yang diacu berada di luar teks, hubungan referensinya disebut eksofora. Referensi endofora dapat dipilah lagi menjadi dua jenis: yaitu (a) referensi anafora dan (b) referensi katafora (Halliday dalam Lubis, 1993:30). Referensi endofora anafora adalah hubungan antara bagian yang satu dengan bagian lainnya dalam teks yang menunjuk pada sesuatu atau anteseden yang telah disebutkan sebelumnya.

Substitusi (penggantian) adalah proses dan hasil penggantian unsur bahasa oleh unsur lain dalam satuan yang lebih besar. Penggantian dilakukan untuk memperoleh unsur pembeda atau menjelaskan struktur tertentu (Kridalaksana, 1984:100). Berbeda dengan referensi yang mengutamakan hubungan makna, substitusi ini lebih mengutamakan hubungan gramatikal. Dengan demikian, pada substitusi ini hubungan itu bukan pada maknanya, tetapi pada gramatikal dan kosa katanya. Substitusi dibedakan atas (1) substitusi nominal, (2) substitusi verbal, dan (3) substitusi klausal. Substitusi nominal terjadi jika satuan bahasa yang disubstitusi berupa nomina. Substitusi verbal terjadi jika satuan bahasa yang disubstitusi berupa verba. Adapun substitusi klausal terjadi jika satuan bahasa yang disubstitusi berupa klausa.

Elipsi adalah proses penghilangan kata atau satuan-satuan bahasa lain yang dapat dimunculkan kembali dalam pemahamannya. Bentuk atau unsur yang dilesapkan dapat diperkirakan wujudnya dari konteks bahasa atau konteks luar bahasa (Kridalaksana, 1984:40). Elipsis juga merupakan penggantian unsur kosong (zero), yaitu unsur yang sebenarnya ada tetapi sengaja dihilangkan atau disembunyikan. Tujuan pemakaian elipsis ini adalah untuk efektivitas dan efisiensi berbahasa.

Konjungsi (kata sambung) adalah bentuk atau satuan bahasa yang berfungsi sebagai penyambung, perangkai, atau penghubung kata dengan kata, frasa dengan frasa, klausa dengan klausa, kalimat dengan kalimat, bahkan paragraf dengan paragraf (Kridalaksana, 1984:105; Tarigan, 1987:101). Konjungsi disebut juga sarana perangkai unsur-unsur kewacanaan. Konjungsi atau penghubungan dengan bantuan kata sambung ini besar perannya dalam mewujudkan kohesi gramatikal perhatikan bahwa di sini kata konjungsi digunakan sebagai salah satu jenis kohesi gramatikal sekaligus sebagai alat gramatikalnya.

Fakultas Keguruan dan Ilmu Pendidikan 
Repetisi adalah pengulangan kata atau frasa yang sama pada kalimat berikutnya untuk memberikan penekanan bahwa kata atau frasa tersebut merupakan fokus pembicaraan. Sinonimi adalah hubungan antarkata yang memiliki makna yang sama. Dengan sinonimi, penggunaan kata dalam wacana lebih bervariasi dan menarik. Antonimi adalah hubungan antarkata yang beroposisi (berlawanan makna). Kata-kata yang beroposisi dengan selaras membuat mitra tutur atau pembaca lebih cepat memahami wacana. Hiponimi adalah hubungan antara kata yang bermakna spesifiks (khusus) dan kata yang bermakna generik (umum). Dalam hubungan hiponimi ini, hipernim (kata umum) tidak perlu disebutkan di depan hiponiminya. Dengan demikian, penggunaan hiponimi ini menjadikan wacana lebih efisien. Kolokasi (sanding kata) adalah hubungan antarkata yang berada pada lingkungan atau bidang yang sama. Kesalahan dalam koherensi merupakan kesalahan wacana yang dalam setiap kata dan kalimat tidak mengandung sebuah gagasan karena maknanya tidak saling berkaitan, menyimpang dari kaidah Bahasa Indonesia. Model kesalahan seperti ini berkaitan dengan faktor kekurangpahaman terhadap wacana baku dalam Bahasa Indonesia, dan ketaksaan/ambiguitas dalam wacana iklan produk-produk Indonesia.Oleh karena itu perlu adanya pengakajian aspek kesalahan wacana pada iklan iklan produk Indonesia agar tidak terjadi pinyimpanganpenyimpangan kebahasaan pada iklan produk produk Indonesia. Pada bagian hasil dan pembahasan, penulis akan menganalisis 10 kesalahan dari masing-masing teks iklan penawaran produk Indonesia yang berbeda berdasarkan aspek aspek kesalahan wacana telah dipaparkan.

\section{METODE PENELITIAN}

Penelitian ini melalui dua tahap yaitu tahap pengumpulan data dan analisis data. Subjek penelitian ini berupa iklan produkproduk Indonesia. Objek penelitian ini berupa analisis kesalahan berbahasa Indonesia di bidang wacana.. Penelitian ini merupakan penelitian deskriptif. Sumber data berasal dari iklan produk-produk Indonesia yang kami dapat dari media massa. Dalam penelitian ini menggunakan teknik pengumpulan data berupa teknik sadap yang diikuti dengan simak, bebas libat, dan cakap. Karena menggunakan bahasa secara tertulis, yaitu dengan cara mencatat bentuk yang relevan untuk meneliti hal ini (Mahsun, 2005: 92). Analisis data yang digunakan dalam penelitian ini adalah padan ekstralingual dengan teknik lanjutan, teknik hubung banding membedakan, atau teknik HBB (Mahsun, 2005: 92). 


\section{HASIL PEMBAHASAN}

Seperti yang telah diketahui bahwasannya iklan produk-produk Indonesia sangatlah banyak. Barang yang dipromosikan tidak hanya sekadar makanan dan minuman saja, ada banyak jenis produk lainnya yang memang diproduksi oleh pabrik di Indonesia. Pada sebuah iklan sering dijumpai adanya bahasa tulis berupa teks singkat guna mendeskripsikan produk sekaligus mempromosikannya kepada masyarakat. Format iklan yang demikian merupakan bagian dari iklan penawaran.

Walaupun singkat, bahasa tulis (teks) yang terdapat dalam iklan produkproduk Indonesia tidak terlepas dari aspek wacana. Masih ditemukan adanya kesalahan wacana pada teks iklan tersebut. Hal itulah yang menjadi fokus utama pembahasan dalam artikel jurnal ini, yakni memaparkan hasil analisis kesalahan wacana pada teks iklan produk-produk Indonesia.

Pada bagian hasil dan pembahasan, penulis akan menganalisis 10 kesalahan dari masing-masing teks iklan penawaran yang berbeda. Hal ini dikarenakan tidak semua teks iklan produkproduk Indonesia memiliki kesalahan di bidang wacana. Analisis ini disesuaikan dengan kajian teori tentang analisis kesalahan wacana yang sebelumnya telah dijelaskan.

\section{A. Kesalahan dalam Kohesi}

1. Kesalahan

Penggunaan

\section{Pengacuan (Referensi)}

Kesalahan penggunaan pe ngacuan berkaitan dengan realisasi benda, subjek, dan proses peristiwa yang tidak sesuai dengan acuan yang dikehendaki pembicara atau penulis. Berikut data kesalahan penggunaan pengacuan yang terdapat dalam iklan susu Nestle Bear Brand.

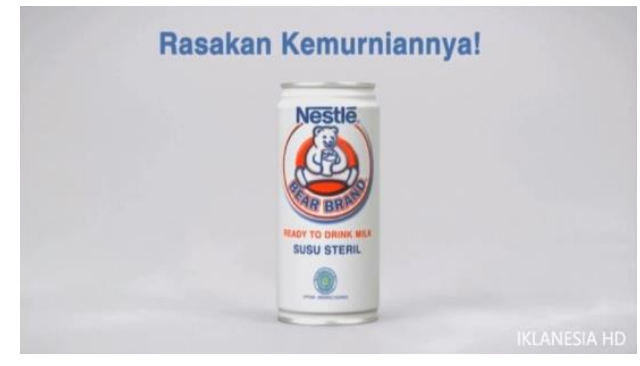

Gambar 1. Iklan susu Nestle Bear

Brand.

Data :

\subsection{Rasakan kemurniannya!}

Pada data 1.1 terdapat kata kemurniannya sebagai pengacuan yang tidak tepat. Rasakan kemurniannya! adalah wacana yang berdiri sendiri tanpa adanya pengacuan, maka dapat dinyatakan bahwa arah acuannya tidak jelas kepada sesuatu apa.

Kemurniannya dalam wacana iklan susu Nestle Bear Brand seharusnya mengacu 
pada produk itu sendiri. Jadi, wacana iklan tersebut dapat diperbaiki menjadi :

Rasakan kemurnian susu Nestle Bear Brand!

\section{Kesalahan}

Penggunaan

\section{Penyulihan (Substitution)}

Kesalahan penggunaan pe

nyulihan yaitu ketidaktepatan penggantian kata yang maknanya sangat berbeda dengan kata yang diacunya. Berikut data kesalahan penggunaan penyulihan yang terdapat dalam iklan Veet dan iklan Kentucky Fried Chicken (KFC) Indonesia.

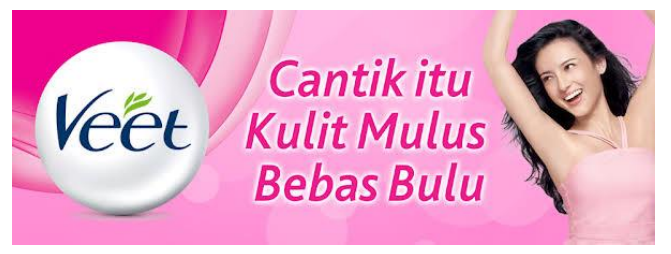

Gambar 2. Iklan Veet.

Data :

2.1 Cantik itu kulit mulus bebas bulu.

Pada data 2.1 dinyatakan bahwa cantik itu yang kulitnya mulus bebas bulu. Perlu diketahui bahwa produk Veet adalah salah satu produk kecantikan buatan pabrik Indonesia. Produk ini berwujud cream yang digunakan untuk menghilangkan rambut yang tumbuh di area ketiak, tangan, dan kaki wanita. Sesungguhnya manusia memiliki (tumbuh) rambut, bukan bulu. Bulu hanya dikhususkan untuk hewan, bukan manusia. Jadi, terdapat kesalahan penyulihan pada kata bulu. Wacana iklan tersebut dapat diperbaiki menjadi:

Cantik itu kulit mulus bebas rambut.

Catatan : hanya rambut yang tumbuh di area ketiak, tangan, dan kaki wanita.

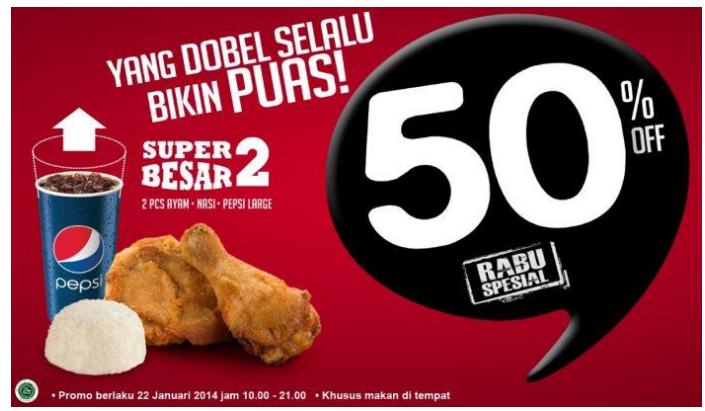

Gambar 3. Iklan Kentucky Fried (KFC) Indonesia.

Data :

2.2 Promo berlaku 22 Januari 2014

pukul $10.00-21.00$

Berhubung wacana iklan Kentucky Fried Chicken (KFC) Indonesia pada gambar 
pertama kurang jelas, maka di bawahnya diberi gambar tambahan versi diperbesar (zoom). Kesalahan penyulihan terdapat pada kata jam. Kata yang diacu oleh kata jam adalah waktu, yakni $10.00-$ 21.00. Pada aturan bahasa Indonesia, untuk megacu waktu yang mengandung keterangan dalam bentuk angka lebih tepat menggunakan kata pukul sebagai acuannya (bukan jam). Kata jam lebih tepat digunakan sebagai acuan benda yang berfungsi menunjukkan keterangan waktu (jadi bukan waktu-nya, tetapi bendanya). Oleh karena itu, wacana iklan Kentucky Fried Chicken (KFC) Indonesia dapat diperbaiki menjadi :

Promo berlaku 22 Januari 2014 pukul $10.00-21.00$

\section{Ketidakefektifan Wacana karena} Tidak Ada Pelesapan

Ketidakefektifan wacana karena tidak ada pelesapan yaitu penggunaan wacana yang kurang efektif, pemborosan kalimat (tidak ekonomis dalam penggunaan bahasa), dan tidak mencapai aspek kepaduan wacana. Maka sebaiknya kata yang kurang efektif tersebut dilesapkan. Berikut data ketidakefektifan wacana karena tidak ada pelesapan pada wacana iklan Dove Daily Shampoo.

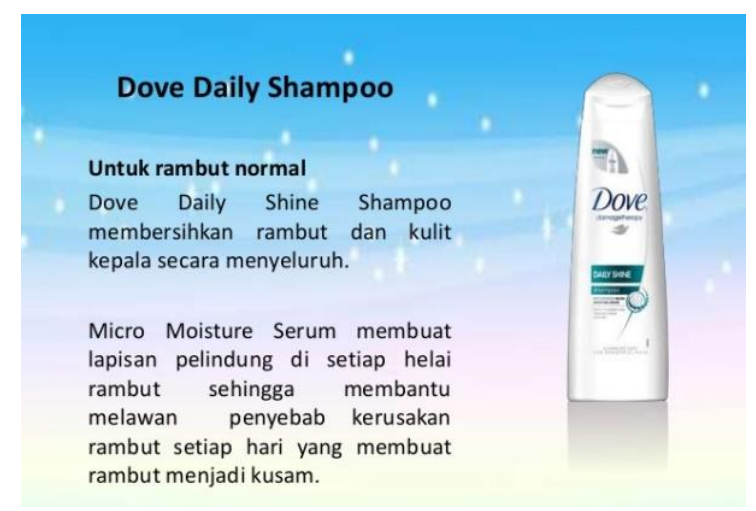

Gambar 4. Iklan Dove Daily Shampoo

Data :

3.1 Micro Moisture Serum membuat lapisan pelindung di setiap helai rambut sehingga membantu melawan penyebab kerusakan rambut setiap hari yang membuat rambut menjadi kusam.

Pada kata rambut dalam iklan di atas merupakan penggunaan wacana yang kurang efektif. Rambut yang dimaksud adalah micro moisture serum yang memberikan perlindungan dalam melawan penyebab kerusakan rambut setiap hari agar tidak terlihat kusam. Jadi, 
perbaikan wacana yang kurang efektif yaitu :

Micro Moisture Serum membuat lapisan pelindung di setiap helai rambut sehingga membantu melawan penyebab kerusakan agar tidak terlihat kusam.

\section{Kesalahan Penggunaan Konjungsi}

Kesalahan penggunaan konjungsi yaitu ketidaktepatan pemilihan dan penempatan konjungsi (kata hubung) guna menghubungkan kata atau kalimat berikutnya. Berikut data kesalahan penggunaan konjungsi yang terdapat dalam iklan pasta gigi Pepsodent.

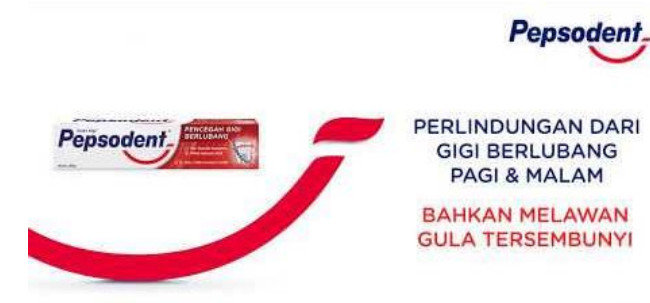

Gambar 5. Iklan Pepsodent.

Data :

4.1 Perlindungan dari gigi berlubang pagi dan malam.

Pada data 4.1 terdapat kata dari sebagai konjungsi yang tidak tepat. Perlindungan yang dimaksud adalah Pepsodent memberi perlindungan untuk gigi yang berlubang pada pagi dan malam hari. Jadi, perbaikan wacana iklan Pepsodent yang tepat yaitu:

Perlindungan untuk gigi berlubang pagi dan malam.

\section{B. Kesalahan dalam Koherensi}

\section{Wacana Tidak Koherens}

Wacana tidak koherens merupakan kesalahan wacana yang dalam setiap kata dan kalimat tidak mengandung sebuah gagasan karena maknanya tidak saling berkaitan. Berikut data kesalahan wacana tidak koherens yang terdapat dalam iklan susu Hilo.

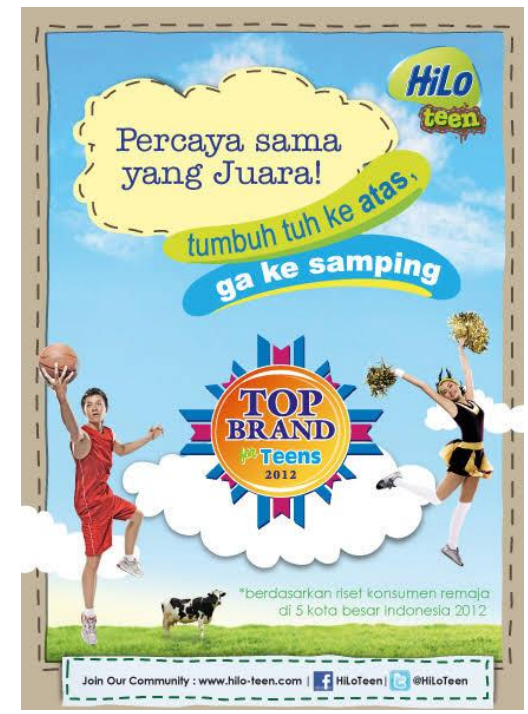

Gambar 6. Iklan susu Hilo.

Data :

1.1 Percaya sama yang juara.

Pada data di atas terdapat kata sama yang digunakan 
untuk menyatakan hal yang tidak sama. Jika dikaitkan dengan logika bahasa, penggunaan kata seperti ini dinyatakan tidak tepat. Begini penjelasannya, berdasarkan wacana iklan susu Hilo, dari segi arti dan penggunaan kata percaya dengan yang juara tidaklah sama. Itu adalah dua hal yang berbeda. Wacana ini sebagai bentuk kalimat persuasif yang menyatakan bahwa dengan rutin megonsumsi susu Hilo kelak akan menjadi sang juara. Oleh karena itu, para calon konsumen diminta untuk percaya kepada sang juara. Jadi, perbaikan wacana iklan susu Hilo yang tepat yaitu:

Percaya kepada sang juara.

\section{Menyimpang dari Kaidah Bahasa Indonesia}

Model kesalahan seperti ini berkaitan dengan faktor kekurangpahaman terhadap wacana baku dalam Bahasa Indonesia. Selain itu, kebiasaan menggunakan kalimat yang salah (tidak sesuai dengan aturan kebahasaan) dalam berkomunikasi juga merupakan penyebab dari timbulnya kesalahan yang meyimpang dari kaidah Bahasa
Indonesia. Berikut ini adalah data kesalahan wacana yang meyimpang dari kaidah Bahasa Indonesia yang terdapat dalam iklan permen Kiss dan minuman Sprite.

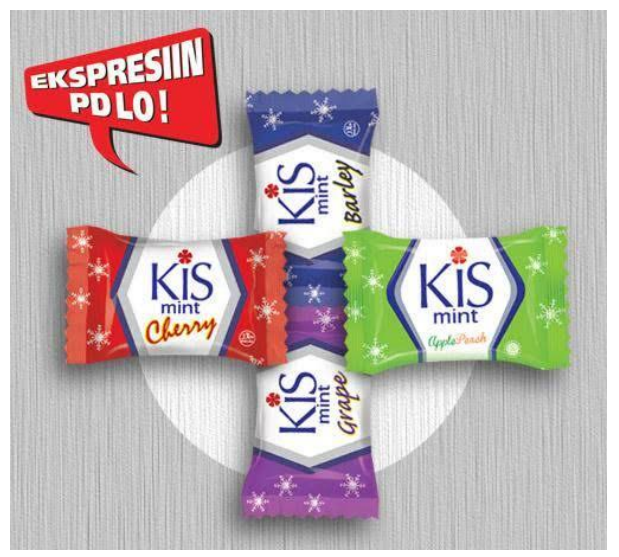

Gambar 7. Iklan permen Kiss.

Data :

\section{Ekspresiin PD lo!}

Kesalahan pertama terdapat pada kata ekspresiin. Sebagai kata yang tidak baku, kata tersebut tidak ada di dalam KBBI. Pembenaran dari kata ekspresiin yaitu ekspresikan. Kemudian terdapat kata $P D$ yang merupakan singkatan dari Percaya Diri (ini bukan termasuk kesalahan). Kesalahan kedua terdapat pada kata lo yang sudah jelas menyimpang dari kaidah kebahasaan. Kata lo artinya kamu. Kata lo biasa dipakai oleh orangorang (termasuk anak muda) dari daerah tertentu, yakni Jakarta. Berdasarkan dua kesalahan tersebut, 
maka wacana dalam iklan permen

Kiss dapat diperbaiki menjadi :

Ekspresikan PD mu!

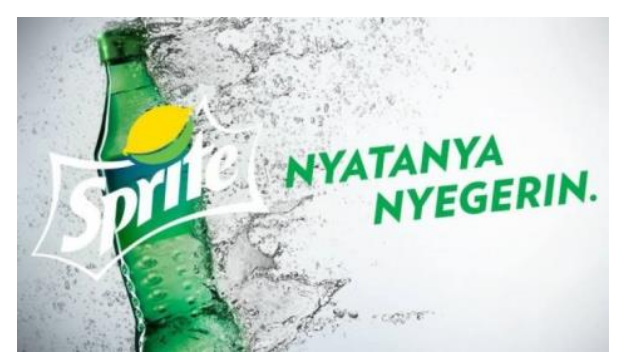

Gambar 8. Iklan minuman Sprite.

Data :

\section{Nyatanya nyegerin.}

Kesalahan pada wacana iklan Sprite terdapat pada kata nyegerin yang tidak mengikuti kaidah bahasa Indonesia. Kata nyegerin sebetulnya berasal dari kata dasar segar. Jika konteks penggunaannya mengarah pada kerja, maka yang baku adalah menyegarkan bukan nyegerin.

Berikut perbaikan pada wacana iklan Sprite :

Nyatanya menyegarkan.

\section{Ketaksaan}

Sering ditemui adanya ketaksaan/ambiguitas dalam wacana iklan produk-produk Indonesia. Hal ini dapat menimbulkan kesalahpahaman oleh pembaca. Penulis menemukan adanya ketaksaan pada wacana iklan provider 3 Indonesia dan Puyer 16 Bintang Toedjoe.

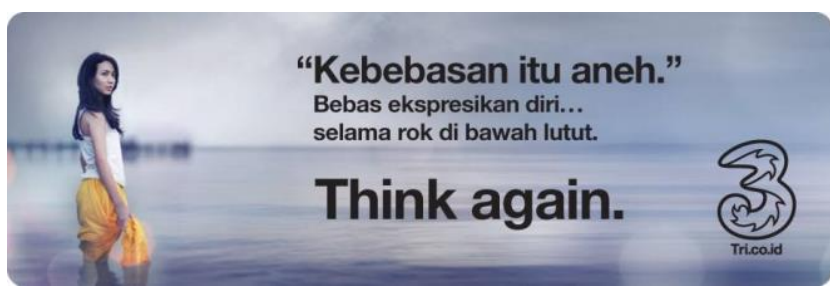

Gambar 9. Iklan provider 3 Indonesia.

Data :

1. Kebebasan itu aneh.

Bebas ekspresikan diri...

\section{Selama rok di bawah lutut}

Pada wacana iklan tersebut sebelumnya dinyatakan bahwa kebebasan adalah hal yang aneh, seseorang bebas megekspresikan diri tetapi selama rok di bawah lutut. Pernyataan ambigu mulai nampak pada kata aneh. Tidak ada keanehan yang dijelaskan secara spesifik dalam wacana iklan provider 3 Indonesia. Kemudian kalimat berikutnya bebas ekspresikan diri... Selama rok di bawah lutut menimbulkan beberapa penafsiran dan pertanyaan; (1) Wacana Selama rok di bawah lutut dapat bermakna ganda: memakai rok tepat di bawah lutut atau panjang roknya yang sampai di bawah lutut? (2) Apakah kebebasan hanya berlaku untuk perempuan yang memakai rok yang panjangnya sampai di bawah lutut saja? (3) Apakah kebebasan yang 
dimaksud hanya untuk perempuan saja? Lantas bagaimana dengan lakilaki yang tidak pakai rok?

Apakah perempuan yang memakai celana tidak berhak mendapat kebebasan?

Berdasarkan

pertanyaan tersebut, dapat dinyatakan bahwa data 1 adalah kalimat ambigu. Wacana tersebut dapat diperbaiki kesalahannya supaya pembaca jelas memahami maknanya. Berikut hasil (sebagai saran) perbaikan :

Kebebasan bagi perempuan itu tidak aneh.

Bebas eskpresikan diri...

Selama memakai rok atau celana yang panjangnya sampai di bawah lutut.

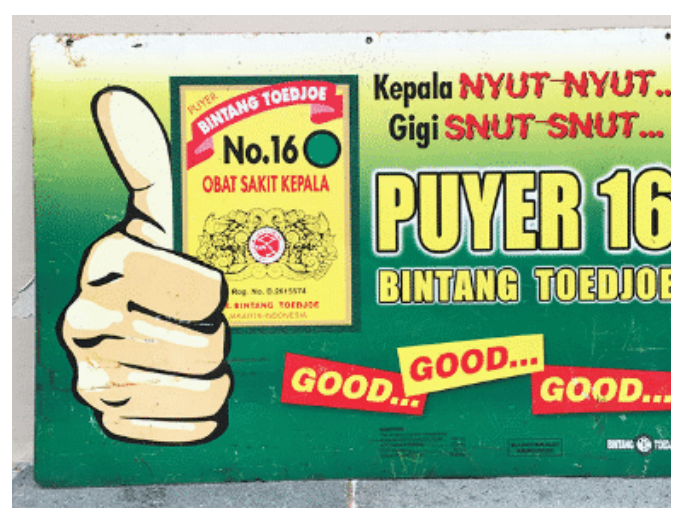

Gambar 10. Iklan Puyer 16 Bintang Toedjoe.

Data :

\section{Kepala nyut - nyut}

Gigi snut - snut

Puyer 16 Bintang Toedjoe
Pada wacana iklan tersebut, pertanyaan ambigu tampak pada kepala nyut - nyut gigi snut - snut Puyer 16 Bintang Toedjoe yang menimbulkan penafsiran makna yang beragam, sebagai contoh yaitu ; (1) Apa maksud kepala nyut - nyut dan gigi snut - snut Puyer 16 Bintang Toedjoe? (2) Apakah maksud dari wacana kepala nyut - nyut dan gigi snut - snut adalah suatu sensasi dari rasa sakit? (3) Apakah Puyer 16 Bintang Toedjoe bermaksud dapat menjadikan kepala nyut - nyut dan gigi snut - snut?

Berdasarkan beberapa pertanyaan di atas dapat dikatakan bahwa wacana iklan Puyer 16 Bintang Toedjoe termasuk ambigu. Wacana tersebut dapat diperbaiki kesalahannya agar tidak menimbulkan kesalahpahaman bagi para pembaca. Berikut hasil perbaikannya:

Sakit kepala nyut - nyut dan sakit gigi snut - snut dapat diatasi oleh Obat Puyer 16 Bintang Toedjoe.

\section{KESIMPULAN}

Secara ringkas simpulan hasil penelitian ini dapat dirumuskan sebagai berikut. Ditemukan adanya beberapa kesalahan berbahasa di bidang wacana pada teks iklan 
produk- produk Indonesia. Berikut 10 jumlah data hasil analisis tersebut. Ditemukan sebanyak 1 data kesalahan penggunaan pengacuan, 2 data kesalahan penggunaan penyulihan (substitution), 1 data ketidakefektifan wacana karena tidak ada pelesapan, 1 data kesalahan konjungsi, 1 data wacana tidak koherens, 2 data kesalahan yang menyimpang dari kaidah Bahasa Indonesia, dan 2 data ketaksaan/ambiguitas.Kesalahan kesalahan kebahasaan yang ditemukan dalam produk iklan di Indonesia diharapkan tidak meluas. Sehubungan dengan hal ini, dalam rangka meminimalkan kesalahan wacana pada produk - produk iklan di Indonesia, pelaku bisnis (khususnya) hendaknya memperluas pengetahuan tentang kaidah Bahasa Indonesia.

\section{DAFTAR PUSTAKA}

Alwi, Hasan. 2002. Kamus Besar Bahasa Indonesia. Jakarta : Balai Pustaka.

Ambarwati, Puji. 2009. Analisis Kesalahan Berbahasa pada Wacana Buku LKS Prisma Mata Pelajaran Bahasa Indonesia untuk SMP [skripsi]. Surakarta (ID) : Universitas Muhammadiyah Surakarta.
Ghufron, Syamsul. 2012. Peranti Kohesi dalam Wacana Tulis Siswa : Perkembangan dan Kesalahannya. Jurnal Bahasa dan Seni, 40 (1), 8193.

Johan, Gio Mohamad. 2018. Analisis Kesalahan Berbahasa Indonesia dalam Proses Diskusi Siswa Sekolah Dasar. Jurnal Pendidikan Bahasa dan Sastra, 18 (1), 136-149.

Kridalaksana, H. 2008. Kamus Linguistik Edisi Keempat. Jakarta: PT Gramedia Pustaka Utama.

Mahsun. 2005. Metode Penelitian Bahasa. Jakarta: RajaGrafindo Persada.

Oktavianus.2006. Analisis Wacana Lintas Bahasa.Padang: Andalas Univeristy Press.

Ramlan, M.1993.Paragaf Alur Pikiran dan Kepaduannya dalam Bahasa Indonesia.Yogyakarta:Andi Offset.

Sari, Ima Yuliana. 2017. Kesalahan Berbahasa dalam Karangan Siswa Kelas X di SMK Negeri 2 Ciamis. Jurnal Diksatrasia, 2 (1), 243-248.

Setyawati, Nanik. 2013. Analisis Kesalahan Berbahasa Indonesia Teori dan Praktik. Surakarta: Yuma Pustaka. 